\title{
Strengthening Field Education: An Integrated Model for Signature Pedagogy in Social Work
}

\author{
Debra Olson-Morrison, PhD \\ Assistant Professor, Social Work Department \\ Park University \\ Tami Radohl, PhD \\ Assistant Professor, Social Work Department \\ Park University \\ Geri Dickey, PhD \\ Associate Professor, Social Work Department \\ Park University
}

\begin{abstract}
Disciplines that incorporate field education into their curriculum face similar challenges around fidelity and tracking of the integration of course work, field learning, and attainment of educational competencies. In social work curriculum, field education is identified as its signature pedagogy (CSWE, 2015), underscoring the importance of in-vivo learning. In this paper, the author's explore challenges associated with integration and assessment of competencies reflective of signature pedagogical principles through a social work lens. The authors propose a model for upholding field education as signature pedagogy through a combination of utilizing a faculty field liaison, housing field education within a course, and by instituting a comprehensive field education learning plan. While specific to social work, the model may generalize to other disciplines struggling to uphold quality in clinical and field education experiences.
\end{abstract}

The integration of classroom learning and field education proves paramount to developing a professional self and arguably is the goal of signature pedagogy in any curriculum. The circular merging of class concepts into students' demonstration of professional competencies through behaviors in the field, followed by the processing of behaviors in the classroom environment demonstrate the bi-directional learning conducive to professional growth. This bi-directional integration of learning also supports the development of critical thinking and identity in the field (Shulman, 2005a; 2005b).

Several professions identify students' practical field learning as their signature pedagogy. Gurung, Haynie, and Chick (2009) identify nursing, occupational therapy, and teacher education as a few professions centered on competencies gained in field experience. Other professions, such as medicine and physical therapy, emphasize the importance of clinical experience (Arena et al., 2017; Rider \& Nawotniak, 2010). Challenges across these disciplines prove similar, such as maintaining fidelity in the field experience, tracking attainment of necessary professional competencies and skills, and integrating requirements set forth by professional accrediting bodies (Greenberg, Pomerance \& Walsh, 2011; Gurung et al, 2009; Polglase \& Treseder, 2012; Schott et al., 2015). While field experiences remain paramount to the student educational experience, competing priorities for faculty to devote time to scholarship, service and 
teaching, combined with budgetary constraints faced by many universities, little attention is given to solutions around how to create higher quality field education experiences (Bogo, 2010).

In 2008, The Council on Social Work Education (CSWE) defined field education as the signature pedagogy in social work education (CSWE, 2008). The updated 2015 Educational Policy and Accreditation standards (EPAS; CSWE, 2015) underscore the centrality of field education in the social work curriculum:

Signature pedagogies are elements of instruction and of socialization that teach future practitioners the fundamental dimensions of professional work in their discipline-to think, to perform, and to act ethically and with integrity. Field education is the signature pedagogy for social work. The intent of field education is to integrate the theoretical and conceptual contribution of the classroom with the practical world of practice setting. It is a basic precept of the social work education that the two interrelated components of the curriculum-classroom and field-are of equal importance within the curriculum, and each contributes to the development of the requisite competencies of professional practice. (p.12)

In this paper, the authors provide a model for an integrative model of field education intended to strengthen conceptual linkage to signature pedagogy. While the paper focuses on a deep investigation of challenges pertaining to social work field education and offers solutions for such challenges, the authors suggest the information proves useful in the study of a SoTL approach to assess what

While field experiences remain paramount to the student educational experience, competing priorities for faculty to devote time to scholarship, service and teaching, combined with budgetary constraints faced by many universities, little attention is given to solutions around how to create higher quality field education experiences.

students are learning in field as it relates to signature pedagogy principles across disciplines (Cornell-Swanson, 2012). The authors offer suggestions for overcoming challenges with implementation of the model while also charging institutions to prioritize excellence in the field education experience.

\section{Signature Pedagogy and Social Work}

Signature pedagogy is defined as "the types of teaching that organize the fundamental ways in which future practitioners are educated for their new professions" (Shulman, 2005a, p. 52), and incorporates three essential components: surface structure, deep structure, and implicit structure. Surface structure comprises the classroom component, where the instructors impart knowledge and education about social work to the student. Deep structure refers to the beliefs and assumptions around how the important components of the education are being taught. Finally, implicit structure encompasses the morals and values of the profession. In social work, the surface structure counts as classroom learning, or the teaching by field supervisors to students about specific practicum duties and obligations. Deep structure is the belief that field and classroom learning function best when one informs the other within the curriculum. In the field, deep structure is the learned behavior in action. Implicit 
structure in social work is encapsulated in our code of ethics and may also be inherently found in social work's nine competencies. As such, the student is expected to behaviorally demonstrate learned acquisition of social work theories, competencies, and ethics. Beyond that, Shulman states that signature pedagogy moves the student into a state of "habits of the mind, habits of the heart, and habits of the hand" (2005a, p.59), an inevitability of learning the basics by rote and then moving beyond them to a place where making informed and critical professional choices are always guided by the backdrop of the structures (Shulman, 2005a; 2005b). Thus, the student becomes deeply engaged, is visible within, and accountable to the profession.

Social work field education strives to meet Schulman's criteria through integration of the core competencies into the surface structure (knowledge learned in the classroom), implicit structure encapsulating integration of social work values and beliefs, and deep structure integrating knowledge and values, as demonstrated in cognitive and affective processes (CSWE, 2015). Much has been written about the theory of signature pedagogy and its application to social work education (Bogo, 2005; Boital \& Fromm, 2014; Cornell-Swanson, 2012; Earls Larrison \& Korr, 2013; Wayne, Bogo, \& Raskin, 2010). The literature provides thoughtful conceptualization on the application of signature pedagogy in developing competent and ethical social work practitioners. Earls Larrison and Korr (2013) argue that signature pedagogy, as defined by Shulman, should focus on "skills fundamental to practitioner competence: to think, to perform and to act with integrity" (p.195). The authors highlight an important aspect of pedagogy, the professional use of self, they believe is currently neglected in CSWE standards. They recommend improved conceptualization of how social work can explicitly define and embrace development of a social worker's ability to integrate education into practice, to develop critical thinking skills, and self-identify as thinking and acting like a social worker (Earls Larrison, \& Korr, 2013; Lee \& Fortune, 2013). Others endorse the view that CSWE does little to support specification or support social work programs in actual design, implementation, and assessment of signature pedagogical principles, resulting in programs falling short of true integration of coursework and field (Wayne et al., 2010; Holosko \& Skinner, 2015). This, in part, may be due to the lack of research on the effectiveness of field education programming (Holden, Barker, Rosenberg, Kuppens, \& Ferrell, 2011) and variability in implementation of field education (Bogo, 2010; Boital \& Fromm, 2014; Holden et al., 2011).

\section{Beyond Social Work: Issues Central to Field Education}

Social work is unique in its use of the term "field education" to describe the signature pedagogy. However, many cross disciplines use experiences in the field to promote learning and engagement within the profession. Student teaching in education curriculum seems most akin to the social work field experience. In a comprehensive report published by The National Council of Teacher Quality (NCTQ; Greeberg, Pomerance, \& Walsh, 2011), student teaching is the semester long final clinical experience where student teachers "synthesize everything they have learned about planning instruction" (p.1). While the report did not name the student teaching experience as the signature pedagogy, it is important to acknowledge the conceptual 
linkages between the student teaching experience and social work students' field practicum. However, in social work field placement is viewed not as a culmination project but as an integral aspect of the learning process in graduate social work education.

In reviewing literature from other disciplines, healthcare sciences, such as physical therapy, occupational therapy, and nursing utilize clinical practices and simulations to assess students' application of applied learning. Further, counseling, psychology and other mental health care disciplines use clinical practice to develop skills for their prospective professions. Yet, the authors failed to locate field education as a signature pedagogy for these professions, and therefore more studies and papers may need to explore the implications of a theoretical framework for field education experiences in these disciplines.

While beyond the scope of this paper, it is important to note that the common challenges across field experiences in nursing, occupational therapy and education are related to assessment, lack of quality placements, lack of qualified supervisors, and lack of a comprehensive framework to support consistency across implementation of learning goals and assessment across field education placements (Cuenca, 2012; Greenberg et al., 2011; Mannix, Faga, Beale, \& Jackson, 2006; Polglase, 2012; Schott et al., 2015). Field education is extensively studied in social work, and therefore provides a solid lens from which to articulate the importance of field education as signature pedagogy, and the challenges of measuring outcomes and assessing fidelity in the field learning environment.

\section{Field Education, Signature Pedagogy and Social Work Educational Policies and Procedures}

The Social Work EPAS stress the importance of behavior assessment of social work competencies, meaning the student should behave in a manner that illustrates and upholds defining social work principles (CSWE, 2015). Arguably, field education provides the environment where students demonstrate behavioral competence of the nine competencies through the integration of course content and field activities. Further, the dimensional component added to the CSWE 2015 Education Policies (knowledge, values, skills, cognitive and affective processes) attempts to capture the totality of processes involved in the acquisition of social work behaviors. Ideally, in social work education, the student transfers classroom learning into an experiential environment where they are required to synthesize learning and reflect on personal and professional issues that arise because of in vivo social work experiences (Boitel \& Fromm, 2014). Lager and Cooke Robbins (2004) sum up the value of the field education experience:

In the field students have the opportunity to test what they learn in the classroom; integrate theory with practice; evaluate the effectiveness of interventions; contend with the realities of social, political and economic injustice; strive for cultural sensitivity and competence; deliberate on the choices posed by ethical dilemmas; develop a sense of self in practice; and build a connection to and identity with the profession. (p. 56) 


\section{Assessing Competence in Field Education}

Beyond integration of course work into field experience, students also must learn how to navigate in a real-world environment while working within the framework of the nine social work competencies. In 2008, CSWE revised the EPAS to emphasize social work as competency-based education measured by student learning outcomes (CSWE, 2008). The 2015 EPAS continues to promote such standards (CSWE, 2015). In the 2015 EPAS, competencies are identified by "the knowledge, skills, cognitive and affective process and behaviors associated with the competence." (CSWE, 2015, p. 11). CSWE defines the purpose of competency-based education as follows: "Social work competence is the ability to integrate and apply social work knowledge, values, and skills to practice situations in a purposeful, professional matter to promote human and community well-being" (2015, p. 6).

CSWE highlights the importance of embracing an outcome-oriented approach rooted in behavioral manifestation of competence: "The goal of an outcomes approach is to ensure that students are able to demonstrate the integration and application of the competencies in practice" (p. 6). Outcomes-based education must, therefore, identify procedures to assess the competencies in a holistic fashion. Student's manifestation of competencies occurs both in and out of the classroom and often demonstrate behaviors related to more than one competency at a time (Poulin \& Matis, 2015). In field education, it is recommended that ongoing and formalized procedures exist to systematically track growth in each competency area. Further, assessment should move beyond simple rating forms where the information provided does little to support how the competency was met (Poulin \& Matis, 2015).

In field education, students must demonstrate knowledge, application, and integration of classroom learning while also explicitly enacting the competencies within practice. Yet, how do monitoring and assessment procedures within social work programs capture such integration? CSWE provides few guidelines on how to assess outcomes in field learning (2015). This may be, in part, because CSWE's policies concerning field education largely focus on the application of the field experience rather than standard procedures for assessing outcomes. However, CSWE does state "field education is systematically designed, supervised, coordinated, and evaluated based on criteria by which students demonstrate the social work competencies" (2015, p. 12).

The lack of guidelines on how to monitor the holistic integration of social work competencies and course learning leads to inconsistencies across schools and departments in monitoring and evaluating practicum learning (Boital \& Fromm, 2014; Earls Larrison \& Korr, 2013; Martin \& Ciarfella, 2015). Further, minimal literature explores the act of "doing" the integration. Different components have been identified as important to field education implementation and assessment, such as a field learning contract (Poulin \& Matis, 2015; Boitel \& Fromm, 2014), use of field liaison (Ligon \& Ward, 2005), and a field In field education, students must demonstrate knowledge, application, and integration of classroom learning while also explicitly enacting the competencies within practice. Yet, how do monitoring and assessment procedures within seminar class with required social work programs capture such integration? 
reflective practice (Boitel \& Fromm, 2014). Yet, no literature was found that provides a thorough and realistic plan for holistic, bi-directional integration. Thus, institutions are left to their discretion as to how they monitor and assess competency and integration. This lack of plan can be problematic when assessing fidelity of implementation and outcomes of the signature pedagogy (Boital \& Fromm, 2014).

Martin and Ciarfella (2015), in their content analysis study examining field education manuals of twenty undergraduate social work programs, identified several discrepancies around the implementation of field education. They found that while some consistencies exist around defining field personnel roles such as training, educational requirements (director, supervisor, and liaison) and gatekeeping procedures, inconsistencies exist in other areas of field education. In particular, the authors found only four of the twenty field education manuals they examined in their study mentioned the social work competencies. Concerning the role of the field liaison, the study found consensus between the manuals in articulating that the faculty liaison serves as the "bridge" between the agency and the educational institution and that the liaison is responsible for assigning grading. The manuals, however, did not specifically address how liaisons assessed and assigned final grades. Of note, Martin and Ciarfella did not research how field education manuals assessed the integration of course and field work, possibly indicating that integration was not a theme in the manuals themselves, or that this concept lacked importance in their investigation.

In preparation for the writing of this manuscript, the authors conducted an exploratory pilot study aiming to elucidate how Master of Social Work programs implement and assess integration of course work into field education and how they monitor the application of the competencies (Olson-Morrison, Dickey, \& Radohl, 2016). The results, while tentative and not generalizable, indicated no clear consistencies or standards for how universities assess outcomes in field education. Learning plans were minimally endorsed, and some institutions assigned grades based on presentations, dialogue, and papers. Some institutions assessed field education learning through seminar classes, while others had no such formal environment for supporting and monitoring student practicum experiences. Further, the data indicated that the monitoring of students in field education was done by a variety of personnel, including part-time non-social work staff, adjunct faculty, and tenured faculty. The report showed a varied picture of how institutions operationalize field education. The findings of this pilot study indicate little cohesion and formality on how departments assess social work's integration of classroom and field or the application of signature pedagogy.

In summary, while an abundance of literature discusses the importance of bidirectional integration of field and classroom and integration of competencies across both (Bogo, 2010; Fortune, et al. 2001; Vayda \& Bogo, 1991; Walden \& Brown, 1985), minimal literature exists on how to monitor and assess the integration of field and course work and the application of the EPAS competencies (Boitel \& Fromm, 2014; Gursansky \& Le Sueur, 2012; Poulin \& Matis, 2015). In failing to specifically focus on integration, the students may dissociate conceptual learning from merely an apprenticeship where skills are learned through imitation and not through developing critical thinking and sense of self (Vayda \& Bogo, 1991), thus failing to meet the standards of a signature pedagogy. 


\section{An Integrative Model for Field Education in Social Work}

Three primary areas for field education emerge from the literature to support the function of an integrated field education as social work's signature pedagogy: the field learning contract, the faculty field liaison, and the seminar course. While not inclusive, these three elements support the application of signature pedagogy in social work curriculum. The first component, the field education learning contract, facilitates the comprehensive assessment of the integration course and field learning, monitors acquisition of competencies, and provides the necessary structure to guide and assess field learning (Boital \& Fromm, 2014; Lee \& Fortune, 2013). The second component centers on the use of a faculty member serving as the field liaison. Currently no guidelines exist in CSWE EPAS (2015) stating who should serve in this capacity, and little guidance or structure is provided in the literature on how programs are to fulfill this role (Ligon \& Ward, 2005; Wayne et al, 2008). However, the field liaison serves as the bridge necessary to facilitate maximum learning and integration of a field education curriculum indicative of a signature pedagogy. Lastly, a field education seminar course provides a space for dialogue and structured learning where the student can be assessed in a classroom environment. While seminar classes have been discussed in the literature specifically related to baccalaureate programming (Poe \& Hunter, 2009), a field education course that functions as a hybrid between a seminar course and no formal course, particularly in master's programs, has yet to be explored.

Therefore, drawing from the literature, in support of the 2015 CSWE EPAS on outcomes and competency-based education and application of signature pedagogy, the authors propose an integrative model of field education that contains the aforementioned three core elements: (1) a formal Field Learning and Education Plan (FLEP); (2) a formal, fully-credited field education course; and (3) a faculty member serving as field liaison (see Figure 1).

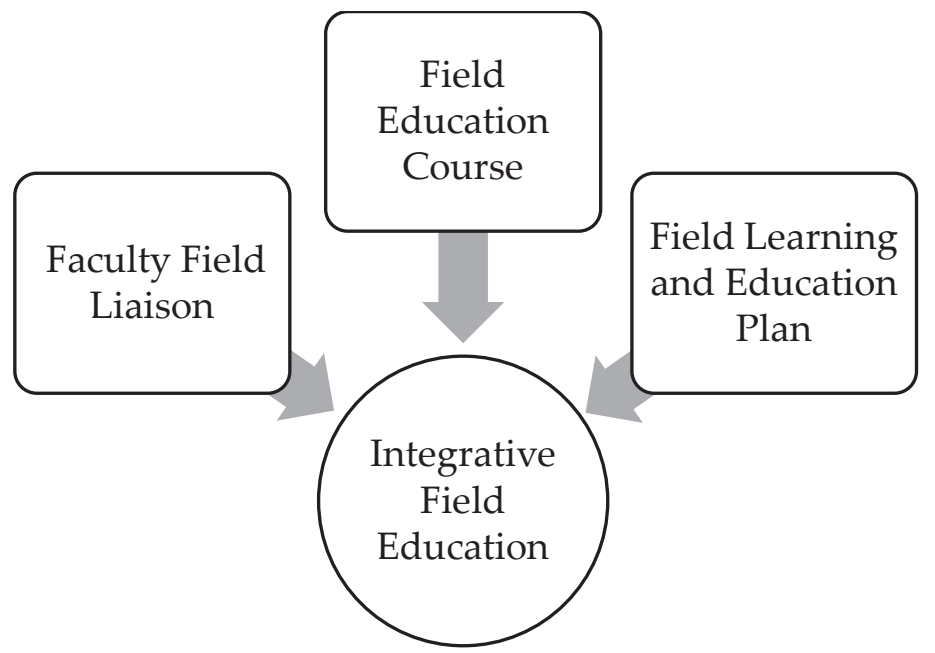

Figure 1. Components of Integrative Field Education as Signature Pedagogy 


\section{The Field Learning and Education Plan}

The field learning contract assesses student performance in field education. It serves as a link between conceptual and experiential learning to provide a structured document that reflects field learning content, objectives, competencies and student goals (Lee \& Fortune, 2013). The contract reinforces and highlights the parallel process occurring between coursework and field and embraces a strengths approach to adult learning in that the student is required to create their own goals based on their perceived learning needs and interests and those of the agency itself (Lee \& Fortune). A field learning contract guides the learning process and supports the outcome-based acquisition of social work competencies. "The learning contract...represents a central element of the signature pedagogy of social work" (Boital \& Fromm, 2014, p. 616). Some studies suggest which elements should be incorporated into a learning contract, but relatively little literature discusses this element of field education (see Boital \& Fromm for review). While master's levels programs may incorporate various types of learning contracts, the literature suggests many schools fail to require a learning plan, or they prove of limited usefulness because they fail to assess the integration of field and coursework (Boital \& Fromm, 2014).

Two recent manuscripts delineate conceptualization of a learning contract. Cleak, Hawkins, Laughton, and Williams (2015) developed a Common Assessment Tool (CAT) that assessed seven key learning areas pertaining to social work competencies. The CAT was designed to be completed by students, field liaisons, and field instructors. In their evaluation of its usefulness, the authors found that the consistency and structure when assessing student outcomes based on social work competencies proved highly useful for adopting pedagogical standards. The CAT was so successful that universities across Victoria Australia adopted this tool as a formalized assessment protocol for field education in social work (Cleak, Hawkins, \& Williams, 2015).

Boital and Fromm (2014) discuss the viability of an integrated learning contract, which utilized theory to enhance the contract's usefulness in developing new learning in student competency behaviors. They suggest that an integrated contract utilize course syllabi to inform the development of goals and objectives for field education. Evaluations of competencies are assessed through observed and written work, and the contract enables the instructor to assess student work across competencies that often are not addressed in the field, such as policy practice and research. Further, the contract promotes the integration of new learning and progress towards competencies. The learning contract utilizes adult learning theory principles, and, beyond integration, captures the learning process through learning transfer and self-awareness (Boital \& Fromm).

Based on the literature and signature pedagogical principles a field learning contract should be designed to incorporate social work competencies and course work (CSWE, 2015), student goals, and systematic evaluations while reinforcing a collaborative team approach in the creation of academic outcomes. The contract should be one comprehensive document that bridges all facets of the field education experience and tracks progress over the duration of the field placement. Evaluation and assessment of integration are assessed through documented behaviors and 
activities and embraces outcomes-based learning. The contract holistically assesses principles of signature pedagogy.

At the author's university, the contract is known as the Field Learning and Education Plan (FLEP). The FLEP contains elements of a contract in that the student agrees to meet educational goals, and the practice behaviors associated with the goals are assessed by the field instructor. However, the "plan' implies that the student and supervisor engage in a dynamic process of creating and revising goals based on the environment, availability of experiences, student's learning priorities, and the necessity of incorporating behaviors associated with competencies. At the onset of the field education course, the student, field instructor, and field liaison should utilize a team approach to create both short-term and long-term goals and outcomes rooted in each social work competency. Further, the team works together to identify tasks, evaluation methods, and anticipated completion dates. Goals and outcomes incorporate specific behaviors, theories, policies, research methods, ethics and values, and other relevant curriculum into the agency setting. Through the goals and objectives, experiences are created to shape students to think, act, and ultimately selfidentify as a social worker

Students are encouraged to assimilate classroom assignments into field experiences and document these expectations on the FLEP, thereby bridging both educational paradigms in social work education. For instance, a generalist practice course might require a student to attend a Board of Director's (BOD) meeting to understand agency culture. Building on this, the field instructor recommends the student help advocate for policy changes at the next board meeting. As a result, the student is able to construct a goal where they attend the BOD meeting, assess boardroom culture, and speak to the board regarding their personal experiences with agency policy. After completion of this goal, they may process this experience with their field instructor- in-supervision to understand the interdependency or intersectionality of different social work concepts as a whole in a real-world situation. This example illustrates the collaborative process and supports the tenets of signature pedagogy, explicitly the integrative process in outcome-based behaviors that demonstrate acquisition of a social work competency.

After goals and outcomes are formulated, the FLEP should be reviewed and updated periodically. Moreover, students and field instructors are encouraged to engage in formal evaluations midway through the semester and at the conclusion of the semester. The FLEP is designed for students and field instructors to work together to rate student performance in each competency area. This ongoing rating procedure, in turn, helps with continued professional development, monitoring of outcomes, and personal reflection of strengths and areas of concern. Because of this arrangement, if student performance concerns exist, they are recognized and addressed quickly. Likewise, if strengths are noted, the FLEP is easily adapted where the team can modify goals and outcomes to further challenge a student's educational experience. The FLEP assists in strengthening students' competencies and confidence in areas of strength and supports growth in areas where skills require further development.

This design of the FLEP incorporates both subjective and objective review rooted in competency behaviors and outcomes. The completion of tasks and goals serves as the objective review. For the subjective review, field instructors and students 
work together to assess progress. One suggestion for review is assigning a numerical reference, using a Likert-Type scale, to observed improvement. This comprehensive FLEP design incorporates essential elements to assess student's acquisition of the three structures (implicit, explicit and deep) important to signature pedagogy (Boital \& Fromm, 2014). An example of the FLEP is shown in Figure 2.

\begin{tabular}{|c|c|c|c|c|}
\hline $\begin{array}{l}\text { Competency 3: Advance } \mathrm{Hu} \\
\text { Environmental Justice }\end{array}$ & man Right & d Soci & omic, ar & \\
\hline Learning Outcomes for & FA & & & RING \\
\hline Competency 3 & EVALU & TION & EVA & UATION \\
\hline & Midterm & Final & Midterm & Final \\
\hline $\begin{array}{l}\text { Understand the forms and } \\
\text { mechanisms of oppression } \\
\text { and discrimination. }\end{array}$ & & & & \\
\hline $\begin{array}{l}\text { Advocate for human rights } \\
\text { and social and economic } \\
\text { justice. }\end{array}$ & & & & \\
\hline $\begin{array}{l}\text { Engage in practices that } \\
\text { advance social and } \\
\text { economic justice. }\end{array}$ & & & & \\
\hline $\begin{array}{l}\text { Learning Activities/Tasks a } \\
\text { Please list the activities and } \\
\text { educational outcomes. Indi }\end{array}$ & $\begin{array}{l}\text { d Completi } \\
\text { tasks that tl } \\
\text { ate the due }\end{array}$ & $\begin{array}{l}n \text { Dates } \\
\text { studen } \\
\text { ate or } t\end{array}$ & $\begin{array}{l}\text { Indertake } \\
\text { activity is }\end{array}$ & $\begin{array}{l}\text { achieve the } \\
\text { ngoing. }\end{array}$ \\
\hline Learning Behaviors: Fall Se & nester & & & Target Dates \\
\hline $\bar{\tau}$ & & & & 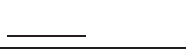 \\
\hline - & & & & - \\
\hline - & & & & - \\
\hline Comments & & & & \\
\hline Updated Behaviors: Spring & Semester & & & \\
\hline$\overline{-}$ & & & & - \\
\hline- & & & & 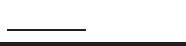 \\
\hline$\widetilde{L}$ & & & & 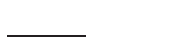 \\
\hline 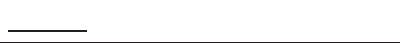 & & & & 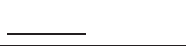 \\
\hline Comments: & & & & \\
\hline
\end{tabular}

Figure 2. A Field Learning and Education Plan (FLEP) 


\section{The Faculty Field Liaison}

Literature explicates the importance of the duties and obligations of the field liaison (Faria, Brownstein, \& Smith, 1988; Hendricks, Finch, \& Franks, 2013; Ligon \& Ward, 2005; Lyter, 2011; Tully, 2015; Urbanowski \& Dwyer, 1988; Wayne et al., 2008). Ligon and Ward (2005) state, “...the liaison has the integral role in student site placements, serving as the link between the institution and field placements, as the evaluator of field educational outcomes, and as administrator of the overall experience" (p. 35). Further, the field liaison serves in the role of advocate, teacher, gatekeeper, mediator advisor and consultant, among other roles (Faria et al., 1988; Hendricks, et al., 2013; Tully, 2015). The liaison is responsible for overseeing the integration of field and coursework as well as documenting behaviorally-based indications of a student's understanding of the social work competencies (Bogo, 2015; Hendricks et al., 2013). Despite the importance of the field liaison role in the social work curriculum, the literature suggests that this position within a department of social work varies. For example, many liaisons are part time, may not teach in the classroom, and may work independently from the university (Hendricks et al., 2013; Tully, 2015).

Ligon and Ward's (2005) survey on field liaison roles found that undergraduate programs devote more time to the liaison role (more time on-site visits and overall student learning) than graduate liaisons, and undergraduate liaisons are more likely to be full-time status than graduate level liaisons. The authors found that less than $75 \%$ of liaisons used a learning plan consistently in conjunction with their field activities. This research highlights two major problems concerning liaisons positions within social work programs: (1) graduate faculty may not be as invested in the field experience despite practicum being identified as the signature pedagogy, and (2) assessing competency in the field is not consistent across universities (Ligon \& Ward, 2005).

When reflecting on the significance of the field liaison to both the student's learning process and the application of program standards, arguable a faculty member would best serve as the field liaison. Further, in an integrative field education model, the faculty field liaison (FFL) should be intimately involved in each student's field education experience. Faculty members broadly and specifically understand how social work pedagogy is manifested into social work curriculum. Consequently, the faculty member can effectively monitor the integration of field and coursework and maintain a constructive relationship between the social work program and the practicum agency.

The FFL monitors integration in several ways. First, written assignments reflect the internalization of explicit and implicit learning. Papers allow students to reflect on thoughts, feelings, and behaviors related to experiential work at their practicums, while also processing how the experiences relate to social work ethics, values, and competencies. Further papers may assess how coursework influences decision-making around using interpersonal skills, techniques, and interventions. The relationship developed by the FFL with the agency also plays a crucial role in student learning (Bogo, 2015). The liaison readily bridges the gap between institution and agency, enabling greater collaboration. Lastly, the FFL can accurately monitor and assess student progress through ongoing oversight and meet with students 
individually and in groups (Tully, 2015) to strengthen integration, reflect and process on experiences, and closely monitor any challenges that may arise. The FFL assigns a letter grade for the field education course, thus holding the student accountable for their learning,

Arguably, using full time faculty members as liaisons may not be feasible at many institutions. Course load, scholarship, and service responsibilities often preclude tasks outside of these realms. Ideally, and field liaison should be knowledgeable with the social work curriculum and the complexities of competency-based education. Adjunct faculty may serve in the role of faculty field liaison, but in this model it is recommended that the adjunct faculty member also have experience with teaching social work curriculum, and their activities be closely monitored and structured by the field education director.

\section{A Field Education Course}

We assert that field education is best housed within a field education course. Literature supports that most of the monitoring of field and course work is done within a field seminar course (Ligon \& Ward, 2005). A collective, peer-based group learning environment offers opportunities for the accountability element of Shulman's (2005; 2005b signature pedagogy requirements. (Wayne et al., 2013). However, and particularly in MSW programs, field education is often viewed as a separate educational component, and thus field education lacks congruence with university coursework (Olson-Morrison, et al., 2016). Results from a pilot study researching integration of field and coursework in CSWE-accredited MSW programs (OlsonMorrison, et al.) indicated that a variety of mediums are used to assess student competency in field education. Some universities used informal mediums of assessment, such as dialogue, while others relied on more formal assessment processes, such as presentations and papers. Further, seminar and course instructors may or may not be a faculty member, which makes the program vulnerable to incongruence between the way students enact outcome-based competency behaviors in field work, and how they are discussed in their seminar classes. The seminar instructor who is not familiar with the students' behaviors in the field assigns a grade based on class assignments rather than rooted in integration and performance.

We propose the solution to this dilemma is the creation of a formalized course where the FFL is also the field seminar instructor. This course is not viewed as separate from the field education component, where students may or may be in a seminar class once or twice a week and the seminar instructor may or may not oversee the practicum placement. Therefore, we used the term "field education course" rather than field seminar to refer to this formalized component. In the classifying of field education as a formal course, the student gains an opportunity to demonstrate integration on all levels, and activities are monitored by the FFL who is also the course instructor. The fully credited course allows the opportunity for the FFL to assess learning and progress on students' FLEP goals, their behaviors related to social work competencies, and through self-reflection and demonstration of applied learning through written assignments and classroom activities. With firsthand knowledge of the placement agency and student's roles within the agency, the FFL also plays a fundamentally 
important role of the bridge between the program and the agency and can assign grades consistent with outcomes based learning. The field education course provides ongoing integrated oversight of the student in the context of both classroom and field, thereby upholding the integrity of field education the signature pedagogy, providing the opportunity for students to demonstrate bi-directional integration on all levels, as monitored by FFL who is also the course instructor. A secondary benefit of the field education course is the FFL can receive course credit towards their required teaching load because the liaison serves as the course instructor. Thus, field education maintains equal status when faculty are dedicated to field instruction and course instruction equally.

The field education course may offer individualized and group instruction. Specific course assignments related directly to integration in field education may include weekly reflection papers, where students discuss behaviors and situations related to competencies and course work applications, and the FLEP. A final paper for the course serves to help the student reflect on personal and professional growth as a social worker. The field instructor may also elect to assess other important areas of field education, such as professional behaviors (showing up on time to practicum, completing paperwork in a timely manner, and even simply dressing appropriately for the agency). All components of the field education course serve to strengthen signature pedagogy principles around learning how to think and act like a social worker (see Table 1).

Table 1

Roles for Each Field Education Component

\begin{tabular}{|c|c|c|}
\hline Faculty Field Liaison & Field Education Course & $\begin{array}{l}\text { Field Learning and } \\
\text { Education Plan }\end{array}$ \\
\hline $\begin{array}{l}\text { Assigns and grades } \\
\text { written work }\end{array}$ & Houses practicum & $\begin{array}{l}\text { Co-created goals and } \\
\text { objectives to behaviorally } \\
\text { demonstrate } \\
\text { competencies }\end{array}$ \\
\hline $\begin{array}{l}\text { Completes overall } \\
\text { assessments for field } \\
\text { education grade } \\
\text { Monitors FLEP }\end{array}$ & $\begin{array}{l}\text { Provides structure for } \\
\text { collaboration between } \\
\text { agency and university as } \\
\text { the FFL is responsible for } \\
\text { assigning course grade }\end{array}$ & $\begin{array}{l}\text { Provides structure for } \\
\text { integrated learning }\end{array}$ \\
\hline $\begin{array}{l}\text { Meets with students } \\
\text { individually and within a } \\
\text { group } \\
\text { Maintains ongoing } \\
\text { documentation } \\
\text { Maintains regular contact } \\
\text { with field instructor }\end{array}$ & $\begin{array}{l}\text { Provides structure for } \\
\text { student learning as they } \\
\text { earn grade in the course } \\
\text { Provides bi-directional } \\
\text { feedback loop }\end{array}$ & \\
\hline
\end{tabular}

InSight: A Journal of Scholarly Teaching 


\section{Recommendations and Generalizability of Model}

By thoroughly exploring a model for social work education, other disciplines may explore how signature pedagogy may be incorporated and assessed in clinical practice. Some commonalities exist across disciplines with maintaining fidelity across student learning experiences and assessment process (Butler \& Cuenca, 2012; Greenberg et al., 2011; Mannix, et al., 2006; Polglase \& Treseder, 2012; Rider \& Nawotniak, 2010). However, the authors noticed that related disciplines commonly use field education as a capstone experience when students have little contact with their educational institution. The capstone model removes opportunities for bidirectional integration of classroom and field. Educational programs may reconsider redefining field education as a course taken simultaneously with other courses that will enhance field learning. They may also consider housing field education in its own course, taught by faculty, that requires graded reflection of how experiences in the field relate to classroom learning and competencies. Synthesizing the competencies of the profession into a comprehensive learning plan used by the field instructor and the liaison enhances integration of field and coursework and maintains a strong connection between agency and university. The learning plan co-created by student, field instructor, and liaison tracks attainment of competencies with fidelity and provides students the opportunity to fully realize the goals of the profession as defined by the signature pedagogy.

Table 2

Using Model Elements to Strengthen Field Education Structure

\begin{tabular}{|c|c|c|}
\hline Current Structure & Strengthened Structure & Element \\
\hline $\begin{array}{l}\text { Field experience is } \\
\text { Capstone, isolates learning } \\
\text { from classroom experience }\end{array}$ & $\begin{array}{l}\text { Field Learning is integrated } \\
\text { into curriculum where } \\
\text { learning is supported by } \\
\text { coursework, with an } \\
\text { emphasis on assessment of } \\
\text { attainment of discipline } \\
\text { competencies and } \\
\text { behaviors }\end{array}$ & Field Education Course \\
\hline $\begin{array}{l}\text { Learning goals are created } \\
\text { by institution or field } \\
\text { director }\end{array}$ & $\begin{array}{l}\text { Learning goals are co- } \\
\text { created by FFL, student } \\
\text { and Field Instructor, and } \\
\text { goals are designed to meet } \\
\text { competencies. }\end{array}$ & $\begin{array}{l}\text { Field Learning and } \\
\text { Education Plan }\end{array}$ \\
\hline $\begin{array}{l}\text { Student is monitored } \\
\text { solely by agency field } \\
\text { instructor with minimal } \\
\text { involvement by the } \\
\text { institution }\end{array}$ & $\begin{array}{l}\text { Student's progress is } \\
\text { monitored by the faculty } \\
\text { field liaison and agency } \\
\text { field instructor, creating } \\
\text { intentional bi-directional } \\
\text { learning experience } \\
\text { between institution and } \\
\text { agency. Assessment is } \\
\text { completed by FFL and field } \\
\text { instructor. }\end{array}$ & Faculty Field Liaison \\
\hline
\end{tabular}


While social work is not unique in incorporating field education, naming field education as the signature pedagogy presents unique challenges. In social work, the model addresses the basic tenant by CSWE (2015) that field education and course work should be given equal weight and share equal importance in curriculum. The authors provide a detailed plan to help guide MSW programs, and programs in related disciplines, to administer field education in such a way that integration of course work and competencies is done with fidelity and integrity. Specifically, it is recommended the faculty liaison be a full time or adjunct faculty member familiar with social work curricula and competencies. The field practicum should be housed in its own course overseen by the faculty field liaison, and as such the student demonstrates integration through written work among other modalities. Finally, the FLEP, co-created by the student, liaison, and field supervisor, should guide the development of the social work student in the context of the professions' competencies. Assessment of students' acquisition of skills and behaviors relating to each competency are assessed by the FLL when applying a grade in the field education course and guided by progress on the FLEP.

It is worth noting that the model presented in this paper has proven successful in the program where it has been implemented for the past four years. Through formal program evaluation assessments completed at the end of the academic year, students report they strongly agree the program bi-directionally integrates course work, field work and competencies. Students and field instructors perceive the FLEP to be effective in promoting growth and attainment of competencies, and students largely feel supported by their FFL. Further, the program has seen less than $10 \%$ disruption in placements over the time period. Students report feeling competent in integrating the competencies into practice and feel confident in their social work skills.

\section{Conclusion}

The purpose of this paper is to explore how field education as a signature pedagogy could be strengthened through an integrative model. The authors use social work's field education programming as an example in order to highlight some of the challenges with field education and also provide a framework to meet such challenges. The integrative framework includes elements supported by literature, specifically in regard to integrating field, course work and competencies, thus providing a conceptual framework for this study. While a moderate amount of literature exists on discussing the implications of field work as a signature pedagogy for social work, minimal literature details operationalization and implementation of programming in social work curricula, specifically in regard to the accomplishment of bi-directional integration implied across all levels of signature pedagogical principles.

As is true in many disciplines, the social work policies for guiding the implementation of field education prove vague. The authors agree with the literature in concluding that the vagueness leads to varying quality of the signature pedagogy (Bogo, 2015). Due to current inconsistencies and dilemmas in administering field education, Bogo calls for the restructuring of field education and moving programs into field-centric models. However, comprehensive restructuring may not prove viable for many institutions, particularly as field liaisons and educators are pressured 
to produce academic scholarly work at the expense of providing quality field education oversight. Further, budget constraints, or even shortages of available faculty to serve as liaisons may prohibit the implementation of such a model.

Field education across disciplines should strive to be more consistent and focused, structured to include elements already supported by the literature. The additions proposed in this paper align with signature pedagogy and strengthen the possibility of providing integrative field education. The framework proposed may assist other professions to strengthen the fidelity of clinical and field experiences and provide students opportunities to more fully identify with their professions.

\section{References}

Arena, R., Girolami, G., Aruin, A., Keil, A., Sainsbury, J., \& Phillips, S. A. (2017). Integrated approaches to physical therapy education: A new comprehensive model from the University of Illinois Chicago. Physiotherapy Theory E Practice, 33, 353360.

doi.org/10.1080/09593985.2017.1305471

Boitel, C. R., \& Fromm, L. R. (2014). Defining signature pedagogy in social work education: Leaning theory and the learning contract. Journal of Social Work and Education, 50, 608-622. doi: 10.1080/10437797.2014.947161

Bogo, M. (2005). Field instruction in social work: A review of the research literature 1999-2005. Clinical Supervisor, 24, 163-193. doi: 10.1300/J001v24n01.09

Bogo, M. (2010). Achieving competence in social work through field education. Toronto, ON: University of Toronto Press.

Bogo, M. (2015). Field education for the clinical social work practice: Best practices and contemporary challenges. Clinical Social Work Journal, 42, 317-324. doi: 10.1007/s10615-015-0526-5
Butler, B. M., \& Cuenca, A. (2012). Conceptualizing the roles of mentor teachers during student teaching. Action in Teacher Education, 34, 296-308. doi.org/10.1080/01626620.2012.717012

Cleak, H., Hawkins, L., Laughton, J., \& Williams, J. (2015). Creating standardized teaching and learning framework for social work field placements. Australian Social Work, 68, 49-64. doi:

10.1080/0312407X.2014.932401

Cornell-Swanson, L. J. (2012). Toward a comprehensive signature pedagogy in social work education. In R. A. Gurung, A. Heynie, \& N. L. Chick (Eds.), Exploring more signature pedagogies: Approaches to teaching disciplinary habits of mind (pp. 203-216). Sterling, VA: Stylus Publishing. Retrieved from http://search.ebscohost.com/login.aspx? direct=true $\&$ AuthType $=$ sso $\& d b=$ nlebk $\&$ $\mathrm{AN}=440869 \&$ site $=$ eds-live \& custid $=083$ 900

Council on Social Work Education (2008). 2008 Educational policy and accreditation standards. Alexandria, VA: author. Retrieved from http://www.cswe.org/Accreditation/EP ASHandbook.aspx 
Council on Social Work Education (2011). 2010 statistics on social work education in the United States. Retrieved from

http://www.cswe.org/File.aspx?id=52269

Council on Social Work Education (2015). 2015 educational policy and accreditation standards. Alexandria, VA. Retrieved from http://www.cswe.org/File.aspx?id=81660

Earls Larrison, T. E., \& Korr, W. S. (2013). Does social work have signature pedagogy? Journal of Social Work Education, 49, 194-206. doi: 10.1080/10437797.2013.768102

Faria, F., Brownstein, C., \& Smith, H. Y. (1988). A survey of field instructors' perceptions of the liaison role. Journal of Social Work Education, 24, 135-144.

Gurung, R. A. R, Chick, N. L., \& Haynie, A. (Eds.) (2009). Exploring signature pedagogies: Approaches to teaching disciplinary habits of mind. Sterling, VA: Stylus.

Greenberg, J. Pomerance, L. \& Walsh, K. (2011) Student teaching in the United States. National Council on Teacher Quality, Washington, DC. Retrieved from https://files.eric.ed.gov/fulltext/ED521916.pdf

Gursansky, D., \& Le Sueur, E. (2012). Conceptualizing field education in the twenty-first century: Contradictions, challenges and opportunities. Social Work Education, 31, 914-931. doi: 10.1080/02615479.2011.595785

Hendricks, C., Finch, J., Franks, C. (2013). Learning to teach, teaching to learn: A guide for social work field education ( $2^{\text {nd }}$ ed.). Alexandria, VA: CSWE Press.
Holden, G., Barker, K., Rosenberg, G., Kuppens, S., \& Ferrell, L. W. (2011). The signature pedagogy of social work: An investigation of evidence. Research on social work practice, 38, 115-133. doi: 1177/1049731510392061

Holosko, M., \& Skinner, J. (2015). A call for coordination leadership to implement the signature pedagogy. Journal of Human Behavior in the Social Environment, 25, 275-283. doi:10.1080/10911359.2015.1005519

Lager, P. B., \& Cooke Robbins, V. (2004). Field education: Exploring the future, expanding the vision. Journal of Social Work Education, 40, 3-12. doi:

10.1080/10437797.2004.10778475

Lee, M., \& Fortune, A. E. (2013). Do we need more "doing" activities or "thinking" activities in field practicum? Journal of Social Work Education, 49, 646-660. doi: 10.1080/10437797.2013.812851

Ligon, J., \& Ward, J. (2005). A national study of the field liaison role in social work education programs in the United States and Puerto Rico. Social Work Education, 24, 235-243. doi: $10.1080 / 0261547052000333153$

Lyter, S. (2011). Potential of field education as signature pedagogy: The field director role. Journal of Social Work Education, 48, 179-188. doi: 10.5175/JSWE.2012.201000005 
Mannix, J., Faga, P., Beale, B., \& Jackson, J. (2006). Towards sustainable models for clinical education in nursing: An ongoing conversation. Nurse Education in Practice, 6, 3-11.

Martin, E. M., \& Ciarfella, T. (2015). The devil is in the details: A content analysis of field manuals. Field Educator, 5(2), 117.

Olson-Morrison, D., Dickey, G. \& Radohl, T. (2016). [A survey of field education practices in CSWE accredited institutions.] Unpublished raw data.

Poe, N. T., \& Hunter, C. A. (2009). A curious curriculum component: The nonmandated "given" of field seminar. The Journal of Baccalaureate Social Work, 14(2), 31-47.

Polglase, T. (2012). The occupational therapy handbook: Practice education. Keswick: M\&K Publishing.

Poulin, J., \& Matis, S. (2015). Perspectives: Social work competencies and multidimensional assessment. Journal of Baccalaureate Social Work, 20, 117-135. doi:

10.18084/1084-7219.20.1.117

Schott, M., Kedia, R., Promes, S. B., Swoboda, T., O'Rourke, K., Green, W., ... \& Santen, S. A, (2015). Direct observation assessment of milestones: Problems with reliability. Western Journal of Emergency Medicine, 16(6), 871876.

doi.org/10.5811/westjem.2015.9.27270
Rider, E. A., \& Nawotniak, R. H. (2010). A practical guide to teaching and assessing the ACGME core competencies $\left(2^{\text {nd }}\right.$ ed.). Danvers, MA: HCPro.

Shulman, L. S. (2005a). Pedagogies of uncertainty. Liberal Education, 91(2), 1825.

Shulman, L. S. (2005b). Signature pedagogies in the professions. Deadalus, 134(3), 52-59. doi: $10.1162 / 0011526054622015$

Tully, G. (2015). The faulty field liaison: an essential role for advancing graduate and undergraduate group work education. Social Work with Groups, 38, 620. doi: 10.1080/01609513.2014.931672

Urbanowski, M. L., \& Dwyer, M. M. (1988). Learning through field instruction: A guide for teachers and students. Milwaukee, WI: Family Services America.

Vayda, E., \& Bogo, M. (1991). A teaching model to unite classroom and field. Journal of Social Work Education, 27, 271278.

Walden, T. \& Brown, L. (1985). The integration seminar: A vehicle for joining theory and practice. Journal of Social Work Education, 21, 13-19.

Wayne, J., Bogo, M., \& Raskin, M. (2010). Field education as the signature pedagogy of social work education. Journal of Social Work Education, 46, 327339. doi: 10.5175/JSWE.2010.200900043 
Debbie Olson-Morrison, PhD, LCSW, RPT is the Director of the MSW Program and Assistant Professor of Social Work at Park University. She earned her MSW in 2001 and PhD in 2009 from University of Utah. Her research focuses on clinical social work in trauma-informed psychotherapy and organizational trauma-informed care, and she is the Founder and Executive Director of New Zealand Trauma Studies Institute. She also serves on the editorial board for International Journal for Play Therapy. At Park University she completed a faculty fellowship on Universal Design and helps oversee Park's food pantry.

Tami Radohl, PhD, LSCSW is the Director of the Center for Research and Training in Integrated Behavioral Health and an Assistant Professor at Park University. Prior to obtaining her doctorate, Dr. Radohl was engaged in direct practice for several years with children, families, and adults. Clinical experience includes school-based mental health, family therapy, outpatient therapy, adoption studies, private practice, and psychiatric assessments. Research interests include family therapy; shared decision making and personal medicine; field education; membership in social work advocacy organizations; interprofessional simulations; and homeless youth. A former Director of Field Education, Dr. Radohl is passionate about field experiences.

Dr. Geri Dickey earned her Bachelor's degree in social work from Southern Illinois University, her Master's degree in social work from the University of Illinois, and her PhD in social work from the University of Missouri. Dr. Dickey spent twenty years of her social work career providing clinical social work services in a variety of hospitals, rehab units, and social work community based clinics. Dr. Dickey's dissertation research study explored the attitudes of certified nurse assistants who work in long term care relative to sexual orientation. The study included the largest group of employees in long term care, (the CNA). Her findings suggested that as advocates for equal rights, social workers have a responsibility to ensure that the sexual orientation of nursing home residents is respected and protected. As an Associate Professor at Park University, Dr. Dickey is currently Chair of Social Work Department.

"Student success has a major impact on the strength and vitality of our democracy. Simply put, student success, for all students, will determine what kind of society we leave for future generations."

George L. Mehaffy and Jo Arney, "Introduction: Re-Imagining the First Year of College (RFY) American Association of State Colleges and Universities," Journal of the Scholarship of Teaching and Learning 